Nadwa : Jurnal Pendidikan Islam

Vol. 12, Nomor 1 Tahun 2018

Accredited by Ristekdikti based on Decree No. 51/E/KPT/2017

\title{
Puasa dan Pendidikan Agama Islam dalam Membangun Manusia Penaka "Tuhan": Tinjauan Kritis Terhadap Sisi Epistemologik dan Aksiologik (Pembelajaran) Pendidikan Agama Islam
}

\author{
Umiarso \\ Universitas Muhammadiyah Malang \\ umiarso@umm.ac.id \\ Makhful \\ Universitas Muhammadiyah Purwokerto
}

\begin{abstract}
:
The focus of the study lies in the relation of fasting with the epistemological and axiologicalside of Islamic religious education. This research used a qualitative approach which focuses on literature study (library research). The result found that fasting is a medium for developing human beings with humanity and divinity potential. This became the foundation of the humanist learning paradigm that made the subject and object of Islamic religious education into human learners; as well as using their learning outcomes for the welfare of mankind and the environment (khalifah) as a form of their devotion to God (abdullah). This human model tends to orient their life to transcendental values (divinity) without ignoring the profane (humanitarian) values; or otherwise take a profane oriented action on values that are transcendentalistic. This is what the humans "duplicate" God.
\end{abstract}

Keyword: Fasting, Learning, and Islamic Religious Education

\begin{abstract}
Abstrak:
Fokus kajian ini terletak pada relasi puasa dengan sisi epistemologik dan aksiologik pendidikan agama Islam. Riset ini menggunakan pendekatan kualitatif dengan jenis studi pustaka (library research). Hasil penelitian menunjukkan bahwa puasa merupakan medium untuk membangun manusia yang memiliki potensi kemanusiaan dan ketuhanan. Hal ini menjadi landasan memunculkan paradigma pembelajaran humanis yang meletakkan subjek dan objek pendidikan agama Islam menjadi manusia pembelajar. Serta menggunakan hasil pembelajaran bagi kesejahteraan umat manusia dan lingkungannya (khalifah) sebagai bentuk pengabdian dirinya kepada Tuhan (abdullah). Model manusia ini cenderung mengorientasikan hidupnya pada nilai-nilai transendental (ketuhanan) tanpa melepaskan nilai-nilai profanistik (kemanusiaan); atau sebaliknya melakukan tindakan yang bersifat profanistik diorientasikan (niatkan) pada nilai-nilai yang bersifat transendentalistik. Inilah yang dikatakan sebagai manusia penaka Tuhan.
\end{abstract}

Kata Kunci: Puasa, Pembelajaran, dan Pendidikan Agama Islam. 


\section{Pendahuluan}

Ali Wasil El Helwany menyatakan bahwa Puasa merupakan wujud kesetaraan ruhani yang dikehendaki syari'ah pada manusia, baik bagi si kaya maupun si miskin sebagaimana kesetaraan individu dalam shalat yang diwajibkan Islam bagi setiap muslim serta kesetaraan sosial dalam kewajiban ibadah haji bagi orang yang mampu melaksanakannya. Kesetaraan ini ditujukan mengiringi jiwa manusia dengan tindakan nyata, bahwa ada kehidupan sejati di balik kehidupan dunia yang nisbi; hanya bisa terwujud dengan kesamaan rasa pada manusia, yaitu saat bersama merasakan keprihatinan, bukan saat berkompetisi mengikuti keinginan (nafsu) yang beragam.1

Sengaja penulis menukil pandangan Ali Wasil El Helwany tersebut untuk membuka kerangka dasar pemikiran filosofis tentang puasa yang dikaitkan dengan konstruksi epistemologis maupun aksiologis pendidikan agama Islam. Pandangan Ali Wasil El Helwany tersebut secara sosiologis memberikan makna spirit humanis-egalitaristik terhadap hakikat kemanusiaan manusia dalam Islam, sehingga pada tataran inilah akan mampu melahirkan tatanan keseimbangan kehidupan di masyarakat sosial. Artinya, jika mengikuti alur pandangan tersebut, puasa dikatakan berkualitas jika mampu membangun dan mengangkat manusia pada stadium humaniti holistik-integralistik,2 yang nantinya ia akan memberikan warna rahmat (manusia yang mampu untuk menjadi pengayom, pencinta, pelindung, dan pemberi kesejahteraan) bagi manusia yang lainnya. Dari urgensitas inilah, pendidikan agama Islam perlu untuk memfokuskan pada kesatuan orientasi antara fakta duniawiyah

1 Ali Wasil El Helwany, Fasting: a Great Medicine (Manfaat Luar Biasa Puasa: Medis, Psikologis dan Spiritual Puasa Wajib ataupun Sunat, Peterj.: Hadiri, dkk., (Depok: IIMaN, 2008), hlm. 44.

2 Disini penulis mengasumsikan bahwa yang dikatakan manusia holistik adalah manusia yang secara menyeluruh merangkul dan mengembangkan semua potensi yang ada dalam dirinya yaitu potensi kemanusiaan (nasut) dan ketuhanan (lasut). Sedangkan manusia integralistik adalah manusia yang mampu menyatukan aspek jasmani (duniawi) dan rohani (ukhrawi). Oleh sebab itu, penulis artikel ini mengistilahkan manusia tersebut dengan manusia yang ada pada stadium humaniti holistik-integralistik. 
dan ukhrawiyah atau ilmu agama dan sains untuk sisi kontributif pada peradaban umat manusia. 3

Secara faktual, kajian tentang puasa yang ditilik dari berbagai perspektif telah banyak melahirkan ragam tulisan mulai dari yang bersifat teoritis sosiologis, filosofis, kesehatan maupun pendidikan; mulai dari yang bersifat non-riset maupun riset. Hal ini tentunya memberikan ragam wawasan bagi penulis-penulis lain untuk mengkaji dari perspektif yang lain atau mengujinya keabsahannya dengan pendekatan yang lain. Tulisan-tulisan tersebut bisa juga dijadikan sebagai acuan teoritis bagi penulis lainnya, sehingga kajian-kajian lainnya mendapatkan ruangruang yang progresif untuk membentuk atau memunculkan teori-teori lainnya. Salah satu tulisan yang cukup relevan dengan kajian ini, adalah tulisan Ahmad Syarifuddin tentang Puasa Menuju Sehat Fisik dan Psikis yang mencoba untuk mendeskripsikan implikasi luar biasa dari puasa bagi kesehatan manusia, baik fisik maupun psikis, sebagaimana standar WHO bahwa sehat itu tidak hanya fisik, tetapi juga psikis, sosial, dan spiritual.4 Juga riset yang dilakukan Abdul Mughni tentang Pengaruh Puasa Ramadhan Terhadap Faktor-Faktor Resiko Aterosklerosis: studi Pada Profil Lipid, Gula Darah, Tekanan Darah dan Berat Badan. Riset ini memunculkan hasil penelitiannya bahwa dari 20 responden penelitian didapatkan penurunan rerata kadar $\operatorname{Tg}(\mathrm{p}=0,02), \mathrm{BB}(\mathrm{p}=0,00)$ dan TDS $(\mathrm{p}=$

3 Hal ini yang sampai saat ini masih menjadi problematika dalam genealogi pendidikan Islam, yaitu akar filosofis dikotomi. Istilah lain dari dikotomi ilmu yang lebih menukik pada akar ilmu adalah pandangan dari A. Malik Fadjar yang mengistilahkan dikotomi ini dengan hellenis untuk ilmu umum atau ilmu modern dan semitis untuk ilmu agama. Gagasan hellenis berasal dari Yunani klasik yang ciri menonjolnya memberikan porsi yang amat besar terhadap otoritas akal, mengutamakan sikap rasional serta lebih menyukai ilmu-ilmu sekuler. Sedangkan gagasan semitis mewarnai alam pikiran kaum agamawan, terutama agama Yahudi dan Nasrani yang mendahului Islam, dengan ciri memberikan porsi yang amat besar kepada otoritas wahyu, sikap patuh terhadap dogma serta berorientasi kepada ilmuilmu keagamaan. Lihat detainya dalam A. Malik Fadjar, Reorientasi Pendidikan Islam, (Jakarta: Yayasan Pendidikan Islam Fajar Dunia, 1999), hlm. 99-100.

4 Ahmad Syarifuddin, Puasa Menuju Sehat Fisik dan Psikis, (Jakarta: Gema Insani Press, 2003). 
0,02) setelah puasa Ramadhan 29 hari dibandingkan dengan setelah tidak puasa 29 hari dan perbedaan rerata kadar kolesterol Total $(\mathrm{p}=0,95)$, kolesterol LDL $(\mathrm{p}=0,86)$, kolesterol HDL $(\mathrm{p}=0,12)$, GDP $(\mathrm{p}=0,46)$ dan TDD $(\mathrm{p}=0,21)$ tidak berubah. Masih riset di dunia kesehatan, ada riset yang dilakukan Eddy Chandra \& Suzanna Ndraha tentang Effect of Omeprazole to Dyspeptic Symptom on Ramadan Fasting Patient Based on Dyspepsia Symptoms Severity Index Scores yang menyimpulkan terjadi penurunan skor DSSI yang bermakna pada kelompok yang menjalankan ibadah puasa dengan terapi omeprazole. Terapi omeprazole $20 \mathrm{mg}$ dua kali sehari selama bulan puasa dapat mengurangi keluhan abdominal pasien dispepsia.5

Sebenarnya puasa merupakan suatu tata ibadah yang masuk dalam lokus keberagamaan personal manusia, sehingga ia sendiri berperilaku sesuai dengan kadar pemahaman, penghayatan, dan pengalaman mereka terhadap ritual ajaran yang dilakukannya tersebut. Dalam keberagamaan personal inilah, kesadaran semangat religiusitas dipahami dalam konteks "menjadi" (becoming) seseorang yang religius untuk terus menerus dalam posisi "ada di hadapan Tuhan" (Ihsan). Implikasi yang muncul adalah pola keberagamaan yang bersifat sosial dengan sifat linieritas antara rentang keimanan mereka dengan perilaku rahmat terhadap sesama atau lingkungan. Konsep yang demikian sebenarnya telah didegungkan oleh beberapa pakar seperti Abdurrahman Mas'ud dengan konsep keseimbangan output pendidikan antara orientasi khalifah dan abdullah, atau Hasan Langgulung dengan konsep insan shaleh.

Artinya, puasa berimplikasi pada kesatuan potensi dalam diri manusia yang akhirnya bermuara pada kemaslahatan diri dan sesamanya. Lazim apabila puasa diyakini memiliki berbagai dimensi dan implikasi-kontributif terhadap diri, sesama, dan lingkungan dilihat dari aspek material maupun maknawi (spiritual). Namun, fakta yang paling penting dari semua aspek tersebut adalah implikasi pada aspek akhlaq dan pendidikan

5 Eddy Chandra \& Suzanna Ndraha, Effect of Omeprazole to Dyspeptic Symptom on Ramadan Fasting Patient Based on Dyspepsia Symptoms Severity Index Scores, dalam The Indonesian Journal of Gastroenterology, Hepatology and Digestive Endoscopy Vol. 14, No. 2 Agustus 2013. 
yang mematangkan kepribadian diri yang melakukan ibadah puasa itu sendiri, maka kesadaran yang terbentuk muncul dari keberagamaan personal mereka sendiri buka dari peniruan (imitasi) dari sikap dan perilaku keberagamaan orang lain (penghayatan impersonal).6 Di mana penghayatan impersonal bukan penghayatan yang berasal dari kesadaran pribadinya sendiri, melainkan didasarkan kepada sifat mengikuti keberagamaan orang lain, kelompok lain atau lembaga-lembaga keagamaan lain dan cenderung bersifat taken for granted (menerima apa adanya tanpa sikap kritis, selektif, dan analitik) terhadap pembentukan keberagamaan lain.

Artinya, jika dilihat dari dimensi ideal, puasa terutama puasa Ramadhan diproyeksikan untuk melatih solidaritas sosial yang memunculkan kemaslahatan umat secara menyeluruh yang tidak hanya dirasakan oleh umat Islam tapi juga umat agama lainnya. Namun, idealitas tersebut seakan-akan hanya bentuk klise semata yang pada tataran empiriknya masih belum membuahkan hasil yang diidealkan. Bahkan jika dilihat secara empiris-generalistik, puasa yang dilakukan bukan memunculkan solidaritas sosial, justru umat Islam cenderung terjebak dalam tindakan-tindakan anarkisme, brutalisme, dan egosentrisme bahkan ia juga membentuk perilaku konsumtif, hedonis, dan pragmatis. Tragisnya lagi, puasa hanya dianggap sebagai ritual yang tidak memberikan pengaruh terhadap hakikat kemanusiaan, sehingga ia tidak mampu untuk membangun kesadaran ketuhanan dalam diri mereka. Wajar apabila kehidupan mereka memiliki pola ketimpangan orientasi dan hal ini berimbas pada tata perilaku mereka ketika ia berinteraksi dengan sesamanya atau lingkungannya yang cenderung lepas dari bingkaian spiritualitas keagamaan dan ketuhanan.

Padahal puasa memiliki tiga fungsi yang semuanya memiliki impiklasi integralistik antara varian kemanusiaan dan ketuhanan. Di mana tiga fungsi tersebut, yaitu: pertama, puasa merupakan sarana untuk mengarahkan (tahzib) seseorang pada hakikat kemanusiaannya; kedua, puasa sebagai pola untuk

6 Tentang keberagamaan ini lihat detailnya Sulthan Ahmad, Dimensi Pengalaman Beragama: Sebuah Tela'ah Fenomenologis dan Antropologis, dalam Jurnal Tajdid Vol. 16, No. 1 Juli 2013, 127-140. 
membentuk karakteristik jiwa seseorang (ta'dib); serta ketiga, puasa sebagai medium latihan untuk berupaya menjadi manusia yang kamil dan paripurna atau manusia penaka Tuhan (tadrib). Tiga fungsi puasa ini bergerak secara sinergis membentuk rentang linieritas yang bermuara pada tujuan akhir yaitu taqwa.7 Taqwa dalam pengertian yang lebih generalistik sebagaimana yang sering didefinisikan oleh para Sufi adalah melindungi diri dari hukuman Tuhan dengan melakukan perintah-Nya dan menjauhi larangan-Nya.8 Pada konteks ini, taqwa lebih diartikan sebagai moralitas ibadah yang terwujud dalam keseimbangan tiap tindakan atau perilaku moral yang integratif.9 Jika demikian, antara taqwa dan keshalehan sosial memiliki relasi yang kuat dan cenderung dalam lokus yang satu seperti dua gambar dalam satu koin.

Posisi itulah yang dalam aksiologi pendidikan agama Islam untuk lebih ditekankan dengan memfokuskan pada konstruksi tujuan akhir. Dan hal inilah yang sebenarnya mendapat penekanan dari Azyumardi Azra bahwa secara analitis tujuan pendidikan (agama) Islam yang ingin diwujudkan nampak pada tujuan akhir (ultimate aims of education) yaitu terletak dalam perwujudan ketertundukan yang sempurna kepada Allah, baik secara pribadi, komunitas maupun seluruh umat manusia.10 Ketertundukan bisa dimaknai sebagai artikulasi dari orientasi

7 Hal ini secara eksplisit termaktub dalam QS. al-Baqarah ayat 183. Di mana Ibnu Katsir ketika memberikan ulasan pada ayat ini menjelaskan bahwa ayat ini ber-khitab kepada orang-orang mukmin dan memerintahkan kepada mereka berpuasa, yaitu menahan diri dari makan dan minum serta bersenggama dengan niat yang ikhlas karena Allah. Karena di dalam berpuasa terkandung hikmah membersihkan jiwa, menyucikannya serta membebaskannya dari endapan-endapan yang buruk (bagi kesehatan tubuh) dan akhlaq-akhlaq yang rendah. Bahkan puasa juga mengandung hikmah menyucikan tubuh dan mempersempit jalan-jalan setan. Al-Imam Abul Fida Isma'il Ibnu Katsir ad-Dimasyqi, Tafsir Ibnu Katsir, Peterj.: Bahrun Abu Bakar, Juz. 2, (Bandung: Sinar Baru Algensindo, 2000), hlm. 150-151.

8 M. Fethullah Gulen, Key Concepts in The Practice of Sufism: Emerald Hills of the Heart, Peterj.: Ali Unal, (New Jersey: The Light, Inc., 2006), 45.

9 Masdar Hilmy, Islam Profetik: Substansiasi Nilai-Nilai Agama dalam Ruang Publik, (Yogyakarta: Kanisius, 2008), hlm. 13.

10 Azyumardi Azra, Pendidikan Islam: Tradisi Dan Modernisasi Menuju Mellenium Baru, (Ciputat: Logos Wacana Ilmu, 2002), hlm.57. 
perwujudan potensi khalifah dan abdullah sekaligus yang dalam paradigmatiknya Hasan Langgulung sering diistilahkan dengan insan shaleh11 atau dalam istilah penulis dikatakan manusia penaka Tuhan. Dari kerangka inilah, diskursus dalam tulisan ini coba untuk ditawarkan sebagai diskursus solutif terhadap dinamika kependidikan Islam yang sedang dalam kondisi dilematis menghadapi keterpecahan orientasi (dikotomik).

Di satu sisi yang lain, konstruksi implikatif puasa di tengah pusaran arus pendidikan agama Islam lebih mengarah pada proses pembelajaran yang lebih menekankan pencapaian tujuan idealitas. Artinya, puasa - di satu sisi mampu memunculkan tatanan nilai ideal sebagai tujuannya- juga bisa mengarahkan pada proses pembelajaran yang lebih efektif untuk diimplementasikan di lembaga pendidikan Islam (atau umum). Oleh karena itu, puasa dapat dikaji secara kritis dari perspektif aksiologik di dalam kerangka tujuan idealnya, dan di satu sisi ia bisa dikaji dari aspek epistemologik sebagai suatu proses pembelajaran. Tidak berlebihan apabila puasa bisa dijadikan sebagai medium untuk mentransformasi diri manusia sebagai makhluk penaka Tuhan, maupun juga sebagai suatu proses pembelajaran untuk menguatkan potensi ketuhanan manusia. Kerangka inilah yang menjadi dasar framework penulis dalam kajian kritis ini yang menggunakan pendekatan kualitatif dengan jenis riset studi pustaka (library research). Kajian riset ini diarahkan untuk menuai pola pembelajaran pendidikan agama Islam yang lebih kritis, efektif, dan sistemik dalam mencapai tujuannya.

11 Hasan Langgulung menyebut insan kamil dengan sebutan insan shaleh, yang merupakan tujuan tertinggi dari pendidikan Islam. Membentuk insan shaleh adalah berusaha mengembangkan manusia yang menyembah dan bertaqwa kepada Allah, manusia yang penuh keimanan dan ketaqwaan, iman dan taqwannya kepada Allah dapat dibuktikan dengan amal perbuatan yang dilakukannya. Selain itu, segala fikiran yang tergores dan segala perasaan yang berdetak dijantungnya selalu mengagungkan asma Allah. Ciriciri dari insan shaleh seperti memiliki sikap terbuka pada alam dan mencari rahasia serta hikmahnya, ia bekerja tidak sekedar kerja namun kerjanya dianggap ibadah, berprinsip hanya kepada Allah dan memiliki rasa kasih sayang kepada sesama. Lihat detailnya Hasan Langgulung, Pendidikan Islam Menghadapi Abad Ke-21, (Jakarta: Pustaka al-Husna, 1998), hlm. 137. 


\section{Manusia Penaka Tuhan}

Pada tataran konseptual-normatif, nilai-nilai yang perlu dikembangkan di dalam tujuan pendidikan agama Islam ialah nilai-nilai yang bersifat fundamental seperti nilai-nilai sosial, ilmiah, moral dan agama. Namun, nilai-nilai tersebut perlu memiliki kompetensi-konstruktif yang bisa untuk mengembalikan hakikat kemanusiaan subjek pendidikan. Sebab, sebagaimana analisa-kritis dari Husain Heriyanto, salah satu problem akut manusia modern kontemporer adalah aliansi dan reifikasi. Aliansi, mengutip pandangan Erich Fromm, adalah sebuah penyakit mental yang ditandai oleh perasaan keterasingan dari segala sesuatu: sesama manusia, alam, Tuhan, dan jati dirinya sendiri. Hal ini terkait dengan gejala reinifikasi (pembendaan, objektivikasi) bahwa manusia modern menghayati dirinya sendiri sebagai benda, objek; yang pada gilirannya, dunia pun hanya dianggap sebagai kumpulan faktafakta kosong (tanpa makna dan nilai).12 Ini artinya, ia mengalami "kecelakaan ontologik" dalam memandang hakikat dirinya sendiri, di mana potensi ketuhanan (lahut) dan kemanusiaan (nasut) dalam dirinya tereduksi menjadi varian tanpa makna dan nilai.

Manusia pada kondisi tersebut tidak memiliki makna diri sebagai khalifah maupun abdullah, sehingga ia terjebak pada sifat dan perilaku destruktif dan cenderung mendewakan hawa nafsu mereka sendiri dan memandang hidup hanya berelasi dengan nilai profanistik-materialistik semata. Mereka yang masuk dalam kategori tersebut akan mengalami split personality yang terus menerus menjadikan dirinya sebagai hamba terhadap ontos-fisis hingga ia sendiri merasa terasing (teralinasi) dalam memandang hakikat dirinya mereka sendiri. Upaya yang perlu dilakukan ialah mengintegrasikan orientasi filosofis pandangan dunia (worldview) mereka. Artinya, upaya integrasi tersebut adalah melalui integrasi ontologik, epistemologik, dan aksiologik dengan wahyu verbalistik (qauliyah) dan wahyu non

12 Husain Heriyanto, Paradigma Holistik: Dialog Filsafat, Sains, dan Kehidupan Menurut Shadra dan Whitehead, (Jakarta: Teraju, 2003), hlm. viii. 
verbalistik (qauniyah) Tuhan, sehingga ia memiliki orientasi dan landasan integral di dalam paradigmatik kehidupan mereka.

Melalui upaya integralisasi tersebut, manusia -baca subjek pendidikan-akan memiliki pandangan yang lebih komprehensif, generalistik, dan konstruktif terhadap berbagai dinamika kehidupan yang muncul. Ia lebih cenderung untuk mengorientasikan hidupnya pada nilai-nilai transendental (ketuhanan) tanpa melepaskan nilai-nilai profanistiknya (kemanusiaan) atau sebaliknya melakukan tindakan yang bersifat profanistik diorientasikan (niatkan) pada nilai-nilai yang bersifat transendentalistik. Konstruksi hakikat kemanusiaan yang demikian inilah dikatakan sebagai konstruksi manusia penaka Tuhan,13 yaitu suatu konstruksi kemanusiaan yang bisa menyatukan diri mereka dengan diri yang transendental hingga ia mampu memahami hakikat diri mereka dan juga mampu untuk berkontributif terhadap kemaslahatan hakikat diri yang lain. Konstruks hakikat kemanusiaan yang demikian di dalam paradigma esoterik-sufistik dipandang sebagai insan kamil yang merupakan suatu predikat khusus dimiliki oleh manusia yang telah sampai pada stadium "penyatuan esensial dengan Tuhan".14

13 Diskursus tersebut sebenarnya merupakan suatu diskursus klasik yang telah menjadi perbincangan pada era-era klasik sebelum era kita ini. Dalam sejarah filsafat Yunani, pembahasan tentang manusia mendapatkan perhatian yang penuh sejak masa Plato. Para Filosof sebelum Plato, yakni pada abad VI SM., seperti Thales, Anaximandros dan Anaximenes lebih tertarik untuk memikirkan tentang alam (kosmos). Pemikiran Plato tentang manusia kemudian dikembangkan oleh Aristoteles (384-322 SM.) ke bidang etika. Ia menuliskan pemikiran etikanya dalam sebuah buku yang berjudul Nicomachean Ethics. Kemudian pada masa-masa selanjutnya pemikiran tentang manusia berkembang kepada pemikiran etika dan religi yang berusaha mencari hidup yang baik, sehingga filsafat merupakan ajaran yang kemudian berkembang dalam pemikiran keagamaan, seperti yang dinyatakan oleh Plotinus bahwa tujuan hidup manusia adalah mencapai penyatuan dengan Tuhan. Lihat detailnya dalam P.A. Van der Weij, Filsuf-Filsuf Besar Tentang Manusia, Peterj.: K. Bertens, (Jakarta: Gramedia Pustaka Utama, 1991), 12; Musa Asy'ari, Manusia Pembentuk Kebudayaan dalam al-Qur'an, (Yogyakarta: LESFI, 1992), 2; Mohammad Hatta, Alam Pikiran Yunani, (Jakarta: Tinta Mas, 1996), hlm. 34.

14 Abd. Hamid Pujiono, Manusia Menyatu dengan Tuhan, (Surabaya: Target Press, 2003), 7-8; Lihat juga dalam Yusnaril Ali, Manusia Citra Ilahi: 
Jelasnya dari deskripsi tersebut, manusia penaka Tuhan memiliki kesempurnaan hakikat kemanusiaan. Di mana kesempurnaannya tersebut terletak pada kesucian jiwanya, sehingga ia dapat mewujudkan sifat-sifat transendentalistik (allahut) dalam dirinya dan mencapai titik kulminasi dalam pengalaman spiritualitas keagamaannya. Melalui kesempurnaan hakikat kemanusiaan inilah, jiwanya menjadi cermin Tuhan dalam melihat diri-Nya.15 Namun demikian pengalaman spiritual religius tersebut sulit diterima dalam realitas spiritual manusia modern yang lebih mengedepankan parameter kebenaran melalui korespondensi dan koherensi yang pada gilirannya melahirkan aliran-aliran pemikiran rasionalisme, liberalisme, positivisme, materialisme, pragmatisme dan sekulerisme. Semua aliran ini dengan watak dasarnya yang sekuler sudah tercerabut dan lepas dari akar nilai-nilai spiritual yang bercorak scientia sacra (ilmu pengetahuan suci).16

Puasa pada konteks ini merupakan media untuk melakukan transformasi diri dengan mengimitasi sifat-sifat transendental (ketuhanan/al-lahut) -baca kepribadian Tuhan- untuk diinternalisasikan pada diri hakikat kemanusiaan (an-nasut). Puasa pada konteks ini bisa dimaknai sebagai suatu "proses" atau "cawah candradimuka" pembentuk manusia menjadi "penaka Tuhan" yang artikulasinya dalam bentuk khalifah dan abdullah di muka bumi. Melalui puasa sebagai suatu "proses", pendidikan agama Islam perlu untuk melakukan rekonstruksi pada ranah epistemologiknya dengan menyeimbangkan polaritas filosofis, metodologis, dan analogis yang digunakannnya, sehingga nantinya bisa untuk melakukan upaya-upaya strategis untuk mewujudkan cita-idealistik tersebut. Idealisasi manusia penaka Tuhan (insan kamil, insan paripurna, atau insan shaleh) lebih merujuk pada pribadi nabi Muhammad baik dari sisi

Penembangan Konsep Insan Kamil Ibnu 'Arabi Oleh Al-Jilli, (Jakarta: Paramadina, 1997), hlm, 60.

15 M. Dawam Raharjo (Edit.), Insan Kamil Konsepsi Menurut Islam, (Jakarta: Graffiti Press, 1987), hlm.110.

16 G. Plekanof, The Development of The Monist View of History, (Moscow: Foreign Language Publishing House, 1956), 13-14; Frithof Schuon, Understanding Islam, Peterj.: D.M. Matheson, (London: Unwin Paperbacks, 1981), hm. 1. 
keberadaannya sebagai ciptaan (al-khalq) maupun dari sisi ketuhanan (al-haqq). Manusia paripurna dapat mencapai kesempurnaan sebagaimana yang dialami oleh nabi Muhammad dengan pengalaman tajallî Tuhan pada dirinya.

\section{Epistemologi Pendidikan (Agama) Islam}

Epistemologi dalam terminologi Arab disebut nadhariyyah al-ma'rifah atau teori ilmu pengetahuan merupakan salah satu cabang filsafat yang mengurai dan menganalisis tentang hakikat dan ruang lingkup pengetahuan, dasar-dasar serta postulasipostulasi yang berkembang serta pertanggungjawaban atas pertanyaan mengenai pengetahuan tersebut.17 Namun ada pandangan lain yang lebih menukik bahwa epistemologi ini merupakan cabang filsafat yang membicarakan mengenai hakikat ilmu, dan ilmu sebagai proses adalah usaha pemikiran yang sistematik dan metodik untuk menemukan prinsip kebenaran yang terdapat pada suatu obyek kajian ilmu. Apakah obyek kajian ilmu itu, dan seberapa jauh tingkat kebenaran yang bisa dicapainya dan kebenaran yang bagaimana yang bisa dicapai dalam kajian ilmu, kebenaran obyektif, subyektif, absolut atau relatif. 18

Epistemologi digunakan untuk mengkonstruks teori-teori dalam suatu disiplin ilmu pengetahuan untuk bisa dipertanggungjawabkan secara empiris dan rasional. Dua syarat inilah pada tradisi positivistik menjadi syarat utama tata bangun ilmu pengetahuan; dan memang, menurut Ahmad Tafsir, keterpaduan rasional(isme) dan empiri(isme) dalam satu paket epistemologi melahirkan metode ilmiah (scientific method). 19 Melalui dua syarat ini pulalah kredibilitas-otoritatif ilmu pengetahuan mampu dibuktikan ketangguhannya. Salah satu

17 Tentang hal ini secara komprehensif lihat Robert Audy, Epistemology: A Contemporary Introduction to the Theory of Knowledge, (London: Routledge, 2011).

18 Musa Asy'ari, Filsafat Islam: Sunnah Nabi dalam Berfikir, (Yogyakarta: LEFSi, 2001), hlm. 65.

19 Ahmad Tafsir, Filsafat Umum: Akal dan Hati Sejak Thales Sampai Capra, (Bandung: Remaja Rosdakarya, 2001), hlm.25. 
yang banyak digunakan oleh kalangan ilmuwan adalah falsifikasi Karl R. Popper.

Begitu pula di ranah konstruks anatomi pendidikan Islam, ia tidak bisa lepas dari gerak material sejarah kemanusiaan yang terus menerus mengalami perubahan. Maka dua syarat tersebut melekat kuat dalam pembentukan ilmu pengetahuan pendidikan Islam, sehingga ia tiap saat mengalami proses adaptasi dan inovasi terhadap perkembangan zaman terutama pola ilmu pengetahuan dan tehnologi. Di mana perkembangan tersebut berimplikasi juga pada perubahan paradigma yang digunakan oleh ilmu pengetahuan, akhirnya paradigma yang digunakan sistem pendidikan akan mengalami perubahan pula.20 Karakteristik ini mengisyaratkan, pendidikan Islam tidak akan selamanya akan bersifat kontinu yang lepas dari perubahanperubahan teori di dalamnya. Akan tetapi ia bersifat diskontinu yang memiliki gerak dinamis melalui lompatan dan perubahan drastis; meminjam bahasa Thomas Kuhn, hal inilah yang dinamakan dengan revolusi ilmiah (scientific revolution) yang dalam kerangka pemikiran tersebut muncul konsep tesis, antitesis, dan sintesis.21

Pada konteks inilah, pendidikan Islam memiliki karakteristik yang kuat dengan menempatkan nilai transendental sebagai paradigma tertinggi (ultimate paradigm). Dalam ranah

20 Paradigma pada konteks ini merupakan broad assumptions about how the world works. Kathy S. Stolley, The Basics of Sociology, (London: Greenwood Press, 2005), 21; atau a basic set of beliefs that guide action (satuan dasar keyakinan yang memandu tindakan). John W. Creswell, Qualitative Inquiry and Research Design: Choosing Among Five Approaches, (London: SAGE Publications, 2007), 19; sedangkan secara komprehensif George Ritzer menjelaskan, a paradigm is a fundamental image of the subject matter within a science. It serves to define what should be studied, what questions should be asked, how they should be asked, and what rules should be followed in interpreting the answers obtained. The paradigm is the broadest unit of consensus within a science and serves to differentiate one scientific community (or subcommunity) from another. It subsumes, defines, and interrelates the exemplars, theories, and methods and instruments that exist within it. George Ritzer (Edit.), Encyclopedia of Social Theory, Jilid II, (London: SAGE Publications, 2005), hlm. 543.

21 Lebih detailnya lihat dalam Thomas Kuhn, The Structure of Scientific Revolutions, (Chicago: The University of Chicago Press, 1970). 
ini pendidikan Islam tidak lepas dari kerangka al-Qur'an dan alHadist sebagai paradigma ilmu pengetahuannya, sehingga setiap adanya alur perkembangan dan perubahan zaman, ilmu pengetahuan dan tehnologi didialektikan dengan al-Qur'an dan al-Hadist berlandaskan dua syarat tersebut (empiris dan rasional). Melalui pola dialektis, pendidikan Islam terus menerus mengintegrasikan sisi rasionalitas-empiris sebagai dasar helenistik dengan sisi semitis yang bercorak doktriner-normatif dengan al-Qur'an dan al-Hadist sebagai paradigma tertingginya. Dengan pengertian yang demikian, dari al-Qur'an dan al-Hadist dapat diharapkan suatu konstruksi pengetahuan pendidikan Islam yang memungkinkan memahami realitas sebagaimana alQur'an dan al-Hadist memahaminya.

Pemikiran yang demikian tersebut sebenarnya menempatkan al-Qur'an dan al-Hadist sebagai mode of thought, mode of inquiry, yang kemudian menghasilkan mode of knowing, sehingga menghasilkan tatanan teori pendidikan yang murni lahir dari ajaran Islam. Dengan demikian, meminjam tesis-analisis Kuntowijoyo bahwa paradigma al-Qur'an berarti suatu konstruksi pengetahuan. Konstruksi pengetahuan itu pada mulanya dibangun dengan tujuan agar kita memiliki "hikmah" untuk membentuk perilaku yang sejalan dengan sistem Islam, termasuk sistem ilmu pengetahuannya. Jadi, disamping memberikan gambaran aksiologis, paradigma al-Qur'an juga dapat berfungsi untuk memberikan wawasan epistemologis.22 Dalam kerangka ini memang dibutuhkan masyarakat penafsir (intepreter community), sehingga al-Qur'an dan al-Hadist dengan semangat pembebasan, keadilan sosial, dan ketauhidan (monoteistik) mampu berbicara tentang teori pendidikan dengan manusia kekinian dan kedisinian.

Dari deskripsi tersebut jelasnya wahyu verbal Tuhan (alQur'an) dan al-Hadist ditempatkan dalam boks operasional metodologi tafsir yang berusaha untuk dipahami sebagai konstruks nilai (aksiologik) dan tata bangun ilmu pengetahuan (epistemologik) untuk perkembangan teori-teori pendidikan Islam yang integratif, holistik, dan operasional di wilayah

22 Kuntowijoyo, Paradigma Islam: Intepretasi untuk Aksi, (Bandung: Mizan, 1991),hlm. 327. 
kemanusiaan, sehingga pendidikan Islam tidak monoton berada "di atas langit" yang materi-materinya sangat sulit untuk diterjemahkan dan apabila mampu diterjemahkan ia hanya berorientasi pada aspek ketuhanan dan melepaskan orientasi kemanusiaan. Pada konteks inilah, upaya untuk memahami alQur'an, aktivitas nabi Muhammad dan latar sosio-historisnya (as-Sunnah) pada perumusan kembali suatu teori-teori pendidikan Islam yang utuh, koheren serta berorientasi pada masa kini. Artinya, nilai al-Qur'an (dan al-Hadist) setidaknya untuk bisa melakukan rekonstruksi tatanan teori pendidikan untuk menjawab persoalan-persoalan masyarakat kontemporer sesuai dengan nilai etis illahiyat. Oleh sebab itu, menurut Fazlur Rahman perlu lebih dahulu perumusan pandangan dunia (worldview) al-Qur'an.23

\section{Puasa, al-Qur'an dan Pendidikan Agama Islam}

Dengan alur pemikiran yang telah penulis paparkan tersebut, maka ada beberapa poin yang muncul: pertama, puasa merupakan suatu "proses" dalam melakukan transformasi diri; kedua, melalui puasa akan tercipta manusia penaka Tuhan; dan ketiga, dalam pendidikan agama Islam untuk melahirkan output tersebut perlu adanya tatanan epistemologi yang memiliki keterpaduan antara rasionalitas, empirisitas, dan intuisi dalam satu paket dengan paradigma al-Qur'an dan as-Sunnah. Beberapa poin inilah yang nantinya perlu diintergasikan dalam satu kesatuan utuh pemikiran penulis yang mengarahkan pada

23 Fazlur Rahman, Islam, Peterj: Ahsin Muhammad, (Bandung: Pustaka, 1984), Bab 2: al-Qur'an. Sehubungan dengan perumusan worldview alQur'an ini, Fazlur Rahman mengemukakan bahwa prinsip penafsiran dengan latar belakang sosio-historis tidak diimplementasikan dengan cara yang sama dengan perumusan etika al-Qur'an, atau oleh Kuntowijoyo disebut sebagai nilai normatif praktis. Menurut Fazlur Rahman, untuk pertanyaan-pertanyaan teologis atau metafisis, latar belakang spesisfik turunnya atau asbabun nuzul wahyu tidak dibutuhkan. Hanya saja dalam merumuskan pandangan dunia al-Qur'an tersebut, Fazlur Rahman tampaknya lebih cenderung menggunakan prosedur sintesis. Lebih detailnya tentang pandangan Fazlur Rahman, lihat Fazlur Rahman, Islamic Studies and The Future of Islam, (California: Malibu, 1980); juga Fazlur Rahman, Islam and Modernity. (Chicago: The University of Chicago, 1980); dan Fazlur Rahman, Major Themes Of The Qur'an. (Chicago: Minneapolis Bibliotheca Islamica, 1980). 
suatu grand project of knowledge, yaitu menjadikan al-Qur'an sebagai paradigma ilmu pengetahuan. Di mana paradigma ini dimaksudkan untuk membangun teori-teori ilmu pengetahuan khas Islam yang penulis sebut sebagai ilmu pengetahuan profetik24 khususnya untuk memberikan paradigma pada pendidikan agama Islam. Paradigma ini dimaksudkan nantinya mampu menjadi mode of thought, mode of inquiry yang pada akhirnya menghasilkan mode of knowing. Dengan pengertian paradigmatik ini, yang muncul dari al-Qur'an dapat diharapkan memunculkan suatu konstruksi pengetahuan yang memungkinkan memahami realitas sebagaimana al-Qur'an memahaminya. 25

Artinya, realitas yang dipahami oleh subjek pendidikan agama Islam tidak hanya dipahami secara parsial dan terfregmentalis oleh sekat-sekat material semata. Akan tetapi, ia dipahami secara menyeluruh melalui landasan nilai-nilai ketaqwaan yang bermuara pada konstruksi masyarakat sosial. Hal ini memiliki korelasi kuat dengan ritual puasa sebagai suatu "proses" yang di dalamnya bisa untuk menjadi sarana membangun kesadaran ketuhanan dan berimplikasi pada tatanan sosial. Nurcholish Madjid pada kerangka ini secara normatif menyatakan, puasa bukan hanya sekedar ritualitas tapi juga sarana pengingat Tuhan, dengan kesadaran bahwa Tuhan ada di mana-mana (omnipresent).26 Bentuk kesadaran ketuhanan yang sebenarnya menjadi pendorong kuat untuk mengejawantahkan nilai-nilai normatif Islam yang terkodifikasi dalam al-Qur'an, sehingga untuk memunculkan paradigma al-Qur'an dalam

24 Meminjam istilah dari Kuntowijoyo yang memahami realitas sosial dengan berparadigma al-Qur'an sebagai Ilmu Sosial Profetik, jadi penulis mencoba mengimitasi paradigma tersebut dengan mengubah menjadi Ilmu Pengetahuan Profetik yang nantinya mampu memberikan paradigma bagi pendidikan agama Islam.

25 Kuntowijoyo, Paradigma Islam: Interpretasi ... hlm. 326.

26 Lihat detailnya Nurcholish Madjid, Penghayatan Makna Ibadah Puasa sebagai Pendidikan tentang Kesucian serta Tanggung Jawab Pribadi dan Kemasyarakatan, dalam Budhy Munawar-Rachman (Edit.), Kontekstualisasi Doktrin Islam dalam Sejarah, (Jakarta: Paramadina, 1995), 415; Nurcholish Madjid, Dialog Ramadhan Bersama Cak Nur: Merenungi Makna dan Hikmah Ibadah Puasa, Nuzulul Qur'an, Lailatur Qadr, Zakat, dan Idul Fitri, (Jakarta: Paramadina, 2000),hlm. 8. 
mengkonstruksi pengetahuan dan manusia penaka Tuhan akan sangat mudah untuk diejawantahkan.

Jadi yang terkonstruksi pada aspek ini adalah ilmu pengetahuan yang berbasis al-Qur'an dengan pola pemahaman realitas melalui kacamata al-Qur'an. Dengan demikian, meminjam analisis Kuntowijoyo, paradigma al-Qur'an berarti suatu konstruksi pengetahuan. Konstruksi pengetahuan itu pada mulanya dibangun dengan tujuan agar kita memiliki "hikmah" untuk membentuk perilaku yang sejalan dengan sistem Islam, termasuk sistem ilmu pengetahuannya. Jadi, disamping memberikan gambaran aksiologis, paradigma al-Qur'an juga dapat berfungsi untuk memberikan wawasan epistemologis.27 Salah satu contohnya adalah statemen-statemen yang terdapat dalam al-Qur'an dan al-Hadits merupakan nilai-nilai normatif yang terdiri dari dua varian, yaitu nilai-nilai praktis yang dapat diaktualkan dalam perilaku sehari-hari; dan nilai-nilai yang perlu diterjemahkan dulu dalam bentuk teori sebelum diterapkan dalam perilaku.28

Salah satu pendekatan metodis yang perlu diperkenalkan dalam rangka mendapatkan pemahaman yang komprehensif terhadap al-Qur'an adalah dengan pendekatan sintetik-analitik.29 Pendekatan ini menganggap bahwa pada dasarnya kandungan al-Qur'an itu terdiri dari dua bagian, yaitu: pertama, berisi konsep-konsep yang disebut ideal-type, dan yang kedua, berisi kisah-kisah sejarah dan amsal-amsal yang disebut arche-type. Dalam bagian pertama, al-Qur'an bermaksud membentuk pemahaman yang komprehensif mengenai ajaran Islam. Sedangkan dalam bagian yang kedua, al-Qur'an ingin mengajak melakukan perenungan untuk memperoleh kebjaksanaan (wisdom). Dengan pendekatan sintetik dimaksudkan untuk menonjolkan nilai subjektif-normatifnya, dengan tujuan mengembangkan perspektif etik dan moral individual. Sedangkan dengan pendekatan analitik dimaksudkan untuk menerjemahkan nilai-nilai normatif ke dalam level objektif. Ini

\footnotetext{
27 Kuntowijoyo, Paradigma Islam: Interpretasi ... hlm. 327.

28 Kuntowijoyo, Paradigma Islam: Interpretasi ... hlm. 327170.

29 Kuntowijoyo, Paradigma Islam: Interpretasi ... hlm. 327327.
} 
berarti al-Qur'an harus dirumuskan dalam bentuk konstrukkonstruk teoritis.30

Dengan nilai-nilai normatif al-Qur'an tersebut, konstrukskonstruks teori pendidikan agama Islam lebih "membumi" dengan pola relasi yang kuat terhadap realitas-empirisnya. Salah satunya adalah nilai-nilai implikatif atau hikmah puasa yang terkandung di dalamnya lebih mampu diinternalisasikan dan diterjemahkan pada perilaku empiris. Di satu sisi, pendidikan agama Islam ketika memberikan penguatan konstruksi aksiologis (manusia penaka Tuhan) melalui paradigma alQur'an lebih memiliki ruang yang sangat lebar. Di mana ritualitas puasa menjadi suatu "proses" rentang pertama dalam upaya pengosongan sifat-sifat tercela (takhalli) untuk menuju kesatuan esensial dengan Tuhan (kesempurnaan hakikat kemanusiaan). Pada konteks inilah al-Ghazali membentangkan jalan yang perlu dilalui untuk mencapai kesempurnaan, yaitu pertama, al-takhalliyyah, yaitu upaya pengosongan diri dari sifat-sifat tercela. Kedua, al-tahalliyyah, pengisian kembali dengan sifat-sifat terpuji setelah pengosongan diri dari sifat-sifat tercela. Dan ketiga, melalui upaya-upaya tersebut maka terbentuklah jiwa yang sempurna (muthma'innah), jiwa yang siap menerima tajallî Tuhan. Pada tahap ini manusia mengalami kesempurnaan jiwa, karena ia memperoleh pengetahuan yang hakiki melalui dunia ghaib. 31

Sedangkan al-Qur'an pada posisi ini menjadi paradigma untuk memberi kerangka epistemologis serta aksiologis, sehingga upaya-upaya menuju ke arah kesempurnaan hakikat kemanusiaan sesuai dengan kaidah normatif yang selaras dengan makna transendentalistik dan memberi kontribusi di ranah profanistik. Artinya, puasa sebagai sarana untuk membentuk manusia penaka Tuhan yang memiliki integritas perilaku sebagai khalifah dan abdullah atau sebagai seorang pemimpin dan seorang hamba di dunia yang di dalam dirinya mampu terisi

30 Kuntowijoyo, Paradigma Islam: Interpretasi ... hlm. 327330.

31 Sumanta, al-Insan al-Kamil dalam Perspektif Tasawuf: Studi Komparasi antara Tasawuf al-Ghazali dan al-Jilli, (Disertasi), (Jakarta: Sekolah Pascasarjana Universitas Islam Negeri Syarif Hidayatullah, 2007),hlm. 48. 
cinta untuk sesama, alam (lingkungan), dan Tuhan. Begitu pula dalam kerangka pemikiran tasawuf al-Ghazali, pengertian manusia sempurna adalah manusia yang telah mampu menggabungkan makna batin dengan makna zhahir dari keberadaan dirinya. Manusia sempurna adalah manusia yang cahaya ilmunya tidak menyebabkan padamnya cahaya wara'nya. Begitupun sebaliknya, untuk mencapai tingkat haqiqah, tidak dengan melampaui batasan-batasan syari'ah. Manusia sempurna itu, dibentuk oleh kesempurnaan jiwanya.32

Dalam realitanya, jika lebih detail masuk ke kerangka fenomenologi,33 implikasi itulah yang tidak tercapai oleh kebanyakan umat ketika menjalankan ritualitas puasa. Mereka hanya mendapatkan lapar dan dahaga lahir batin (tidak minum dan seks), sedangkan sisi hikmah dan nilai yang berada di balik puasa tersebut tidak mampu terejawantahkan dalam kehidupan mereka. Walaupun secara kodrati, manusia memiliki kecenderungan pada ritualitas-ritualitas untuk melakukan atau berpantangan makan, minum, dan seks. Hal inilah yang diberi arahan jelas melalui ritualitas puasa agar hal tersebut bisa dibawa ke tingkat yang lebih tinggi, dan dikaitkan dengan unsur ruhaniah (spiritualitas), yakni dimensi ketuhanan. Dengan kata lain, umumnya manusia memiliki ritualitas dalam melakukan atau berpantang dari makan, minum, dan seks sebab berbagai

32 Sumanta, al-Insan al-Kamil ...f, hlm56-57.

33 Istilah fenomenologi berasal dari bahasa Yunani yang artinya ilmu gejala atau ilmu tentang gejala-gejala. Tekanannya adalah kepada keperluan untuk melukiskan gejala-gejala agama tanpa adanya prasangka dari si penilai. Untuk pertama kalinya istilah fenomenologi dipakai oleh J.H. Lambert (1728-1777), seorang ahli matematika dan filsafat. Menurutnya fenomenologi adalah sebuah penyelidikan kritis mengenai hubungan antara sesuatu yang lepas dari pertimbangan dan sesuatu sebagai akibat pengalaman kita, empiris. Secara luas fenomenologi itu adalah ilmu tentang apa saja yang tampak. Dalam hal ini fenomenologi merupakan sebuah pendekatan filsafat yang berpusat pada analisis terhadap gejala yang membanjiri kesadaran manusia. Secara sempit artinya adalah ilmu tentang gejala yang menampakkan diri pada kesadaran manusia. Dengan begitu titik central dalam pengertian ini adalah apa saja fenomena yang bisa dicerap oleh kesadaran manusia. Kesadaran manusia dalam menanggapi fenomena akan menghasilkan pengertian yang murni tentang apa yang sesungguhnya ada dibalik penampakkan gejala. Sulthan Ahmad, Dimensi Pengalaman Beragama ... hlm. 132-133. 
kebutuhan-kebutuhan dasar biologisnya. Padahal ritualitas itu hanya pantas untuk Tuhan semata, ajaran agama kemudian mengajarkan bagaimana ritualitas tersebut (makan, minum, dan seks) dalam dimensi ketuhanan -inilah alasan puasa menjadi ibadah.34

Jelasnya, puasa merupakan suatu "proses" yang di dalamnya ada tatanan nilai dan hikmah untuk membentuk keshalehan sosial yang bertumpu pada kesadaran ketuhanan, sehingga paradigma yang ia pakai adalah paradigma transendental (paradigma al-Qur'an) yang digunakan untuk melihat, memahami, menganalisis realitas kemanusiaan sebagaimana al-Qur'an melihat, memahami dan menganalisis material realitas tersebut. Melalui tatanan inilah, subjek pendidikan agama Islam terbentuk menjadi manusia yang integratif dengan kemampuan menyatukan orientasi mereka dan juga mampu menyatu secara esensial dengan realitas transendental. Di mana predikat ini dikatakan sebagai al-Insan al-Kamil sebagaimana yang dilukiskan oleh Reynold A. Nicholson sebagai orang yang sepenuhnya dapat mencapai kesatuan dengan dzat Tuhan. Dalam hal ini manusia "serupa" dengan Tuhan atau yang oleh penulis dikatakan sebagai manusia penaka Tuhan. Pengalaman semacam ini dicapai oleh para nabi dan para wali. Oleh karena itu, al-Insan al-Kamil bukan hanya atribut bagi para Nabi, akan tetapi juga atribut bagi orang-orang pilihan (khawwash) yang telah mampu meraihnya35 dan orangorang yang yang mampu mencapai serta menemukan tatanan hikmah dan nilai normatif puasa.

\section{Pembelajaran Humanistik dalam Pendidikan Agama Islam}

Sebelum mengurai lebih detail tentang urgensitas dan implikasi puasa dalam pendidikan agama Islam. Penulis memiliki keyakinan bahwa puasa mampu untuk menjadi medium membangun subjek pendidikan yang paripurna. Seperti

34 Nanang Tahqiq, Puasa Ramadlan, dalam Aan Rukmana, dkk., Mengenal Islam Jalan Tengah: Buku Daras Pendidikan Agama Islam untuk Perguruan Tinggi, (Jakarta: Dian Rakyat, 2012), hlm. 220.

35 Reynold A. Nicholson, Studies in Islamic Mysticisme, (London: Cambridge University Press, 1991), hlm. 78. 
tulisan Abdul Jawwad ash-Shawi yang menyatakan bahwa puasa sebagai terapi pembersihan diri, penataan perilaku, juga sebagai terapi pencegahan dan pengobatan dari penyakit-penyakit yang bisa menimpa tubuh dan jiwa manusia akibat terlalu banyak mengonsumsi makanan dan melanggengkannya.36 Atau tulisan Zaprulkhan tentang Puasa Ramadhan Sebagai Terapi Pencerahan Spiritual yang mengurai makna puasa pada aspek sosial (tataran kemasyarakatan atau hubungan manusia dengan manusia).37 Tulisan Jalalluddin Rakhmat tentang Madrasah Ruhaniah: Berguru pada Ilahi di Bulan Suci yang mencoba untuk memaparkan tentang makna puasa dari aspek filsafat dan dampak bagi kehidupan manusia.38 Serta kumpulan tulisan yang suting oleh A. Sudiarja, dkk tentang Karya Lengkap Driyarkara: Esai-Esai Filsafat Pemikir yang Terlibat Penuh dalam Perjuangan Bangsanya. Di mana dalam kumpulan tulisan ini ada penjabaran tentang puasa yang ditilik dari aspek psikologi yang dispesifikasi pada aspek ilmu jiwa fenomenologis. 39

Selain meneguhkan tentang urgensitas puasa, tulisan-tulisan tersebut pada kerangka ini menjadi landasan utama untuk membangun kajian kritis tentang puasa dan pendidikan agama Islam. Memang secara faktual, puasa merupakan medium untuk membangun manusia yang memiliki potensi kemanusiaan dan ketuhanan. Di dalam pendidikan agama Islam hal ini muncul dalam suatu proses yang disebut pembelajaran; di mana proses ini menuntun subjek dan objek pendidikan pada suatu stadium yang lebih tinggi dari sebelumnya mulai dari aspek fisik terlebih psikis mereka. Lazim apabila dikatakan pembelajaran dalam

36 Abdul Jawwad ash-Shawi, Terapi Puasa: Manfaat Puasa Ditinjau dari Perspektif Sains Moderns, Peterj.: Aan Wahyudin, (Jakarta: Republika, 2006), hlm. 135.

37 Zaprulkhan, Puasa Ramadhan sebagai Terapi Pencerahan Spiritual, (Jakarta: Bentang Pustaka, 2007).

38 Jalaluddin Rakhmat, Madrasah Ruhaniah: Berguru Pada Ilahi Di Bulan Suci, (Bandung: Mizan, 2005).

39 A. Sudiarja, dkk (Peny.), Karya Lengkap Driyarkara: Esai-Esai Filsafat Pemikir yang Terlibat Penuh dalam Perjuangan Bangsanya, (Jakarta: diterbitkan atas kerjasama PT. Kompas Media Nusantara, PT. Gramedia Pustaka Utama, dan Kanisius, 2006). 
pendidikan agama Islam merupakan arus utama di dalam usaha untuk menginternalisasikan nilai-nilai transendental di diri subjek dan objek pendidikan. Artinya, pembelajaran merupakan suatu proses yang di dalamnya terdapat pengalamanpengalaman untuk mengasah potensi diri seperti keterampilan diri, kemampuan (pengetahuan) diri, dan lain sebagainya, sehingga ia memiliki kemampuan kompetensi yang sangat tinggi. Kemampuan ini meliputi berbagai aspek yang di dalamnya tersimpul dalam tiga varian besar yaitu IQ, EQ, dan SQ yang semuanya dibentengi oleh nilai-nilai ketauhidan.

Namun, di dalam proses pembelajaran perlu terdapat minimal tiga unsur yang ada dalam pendidikan Islam, antara lain: 1). Proses pengembangan potensi jasmaniah dan rohaniah secara seimbang; 2). Yang perlu didasarkan atas ajaran Islam (al-Qur'an, al-Hadist, dan ijitihad); dan 3). Diarahkan untuk membangun insan kamil.40 Pencapaian yang perlu ada di dalam pembelajaran pendidikan agama Islam adalah pencapaian yang bersifat integratif yang mengantarkan subjek pendidikan pada fase ketaqwaan (ihsan). Sebagaimana puasa yang juga mengantarkan pelakunya pada derajat "ketaqwaan" (QS. AlBaqarah: 183).

Oleh karenanya, kemampuan belajar sebagai hasil proses pembelajaran, maka proses pembelajaran tersebut tidak berhenti dengan selesainya subjek pendidikan menempuh semua disiplin ilmu terlebih berakhirnya pembelajaran pendidikan agama Islam. Proses internalisasi nilai-nilai transendental secara terus menerus dilakukan dan diimplementasikan pada tatanan perilaku keseharian dengan dasar kesadaran diri sebagai makhluk sosial maupun juga sebagai makhluk ketuhanan. Oleh karena itu, kemampuan belajar yang sudah ada akan membawa manusia ke dalam proses pembelajaran sepanjang hayat yang di dalamnya terdapat nilai-nilai ibadah kepada Tuhan semata. Dalam proses belajar sepanjang hayat ini, yang terjadi adalah penyeimbangan

40 Moh. Roqib, Ilmu Pendidikan Islam: Pengembangan Pendidikan Integratif di Sekolah, Keluarga, dan Masyarakat, (Yogyakarta: LKiS, 2009), 20; bandingkan juga M. Suyudi, Pendidikan dalam Perspektif al-Qur'an: Integrasi Epistemologi Bayani, Burhani, dan Irfani, (Yogyakarta: Mikraj, 2005), hlm. 52-55. 
peran logika, ego dan emosi dalam berkata-kata, bersikap, dan berbuat dengan menyelaraskan dengan tuntunan ilahi. Peran logika yang membuat manusia menjadi tahu/mengerti, perlu pula diimbangi dengan peran ego yang meletakkan kepentingan diri dan kepentingan orang lain secara proporsional, dan dengan peran emosi yang memunculkan rasa bahagia dan damai untuk diri mereka dan orang lain. Semua peran tersebut perlu disesuaikan dengan nilai-nilai normatif al-Qur'an, sehingga melalui paradigma Qur'anik inilah dirinya mampu memiliki fungsi untuk memberikan wawasan epistemologis terhadap logika, ego, dan emosi dirinya.

Pembelajaran pendidikan agama Islam pada kerangka ini memunculkan pola pembelajaran humanistik yang mencoba untuk menempatkan subjek dan objek pendidikan pada hakikat yang azali. Paradigma pembelajaran humanistik ini menempatkan setiap subjek dan objek pendidikan agama Islam untuk menjadi manusia pembelajar (learner), menggunakan hasil pembelajarannya guna kesejahteraan seluruh umat manusia dan lingkungannya (khalifah) sebagai bentuk pengabdian dirinya kepada Tuhan semata (abdullah). Jadi pembelajaran ini mengasumsikan dan mengintegrasikan peran manusia pada satu lokus yaitu manusia yang manusiawi sebagai makhluk Tuhan. Sebagaimana yang telah disinyalir oleh Tobroni bahwa pendidikan Islam -baca juga pendidikan agama Islammerupakan pendidikan yang berwawasan semesta, yaitu ketuhanan, kemanusiaan, dan kealaman secara utuh dan integratif. Dengan kata lain, pendidikan Islam berparadigma transendensi (ketuhanan) dan objektifikasi (manusia dan alam). 41

Di sisi yang lain, pembelajaran humanistik ini menempatkan setiap subjek dan objek pendidikan Islam sudah dipastikan merupakan manusia pembelajar yang mampu menujukkan makin seimbangnya peran logika, ego, dan emosi dalam tutur kata dan perilaku kita sehari-hari dengan landasan kesadaran ketuhanan mereka. Pada posisi inilah, puasa

41 Tobroni, Pendidikan Islam: dari Dimensi Paradima Teologis, Filosofis, dan Spiritualitas hingga Dimensi Praksis Normatif, (Jakarta: Mitra Wacana Media, 2015), hlm. 28. 
merupakan suatu medium untuk membentuk manusia penaka Tuhan yang memiliki integritas perilaku sebagai khalifah dan abdullah atau sebagai seorang pemimpin dan seorang hamba di dunia yang di dalam dirinya mampu terisi cinta untuk sesama, alam (lingkungan), dan Tuhan. Peran ini dimotori oleh kesatuan peran antara logika, ego dan emosi dengan landasan kesadaran ketuhanan.

\section{Simpulan}

Dengan demikian, puasa bisa dikatakan sebagai bentuk ritual yang melatih jiwa manusia untuk memiliki sifat-sifat ketuhanan. Sehingga ia mampu membentuk perilaku konstruktif (akhlaq al-karimah) yang muncul dari kesadaran dirinya sebagai khalifah dan abdullah. Begitu pula konstruksi pembelajaran pendidikan agama Islam menekankan pada terbentuknya insan kamil yang mampu mewujudkan potensi dirinya sebagai penebar rahmat terhadap sesama manusia maupun lingkungan. Melalui tata aksiologi inilah, manusia bisa meniru Tuhan untuk menebar kasih-sayang atau rahmat bagi semesta alam. Bisa saja dua entitas ini menjadi rentang proses pembentukan manusia penaka Tuhan. Pertama, puasa bisa menjadi ajang untuk "membuang" dan "mengosongkan" sifat-sifat tercela; dan kedua, pembelajaran pendidikan agama Islam dijadikan sarana untuk mengisi jiwa manusia dengan potensi ketuhanan (sifat wal asma'). Bahkan melalui kerangka kerja puasa sebagai medium membangun jiwa yang mapan, dan melalui dimensi aksiologis puasa yang memunculkan manusia bertaqwa. Maka pendidikan agama Islam bisa meraih kesempurnaan dimensi epistemologik dan aksiologik yang berakhir pada outcome pendidikan dengan kesatuan diri sebagai makhluk sosiologis dan teologis.

\section{Daftar Pustaka}

Ahmad, Sulthan, Dimensi Pengalaman Beragama: Sebuah Tela'ah Fenomenologis dan Antropologis, dalam Jurnal Tajdid Vol. 16, No. 1 Juli 2013. 
Ali, Yusnaril, 1997, Manusia Citra Ilahi: Penembangan Konsep Insan Kamil Ibnu 'Arabi Oleh Al-Jilli, Jakarta: Paramadina.

Asy'ari, Musa, 1992, Manusia Pembentuk Kebudayaan dalam al-Qur'an, Yogyakarta: LESFI. , 2001, Filsafat Islam: Sunnah Nabi dalam Berfikir, Yogyakarta: LESFi.

Audy, Robert, 2011, Epistemology: A Contemporary

Introduction to the Theory of Knowledge, London: Routledge.

Azra, Azyumardi, 2002, Pendidikan Islam: Tradisi Dan Modernisasi Menuju Mellenium Baru, Ciputat: Logos Wacana Ilmu,.

Creswell, John W., 2007, Qualitative Inquiry and Research Design: Choosing Among Five Approaches, London: SAGE Publications,

El Helwany, Ali Wasil, 2008, Fasting: a Great Medicine Manfaat Luar Biasa Puasa: Medis, Psikologis dan Spiritual Puasa Wajib ataupun Sunat, Peterj.: Hadiri, dkk.Depok: IIMaN.

Fadjar, A. Malik, 1999, Reorientasi Pendidikan Islam, Jakarta: Yayasan Pendidikan Islam Fajar Dunia.

G. Plekanof, The Development of The Monist View of History, (Moscow: Foreign Language Publishing House, 1956).

Gulen, M. Fethullah, 2006, Key Concepts in The Practice of Sufism: Emerald Hills of the Heart, Peterj.: Ali Unal, New Jersey: The Light, Inc.

Hatta, Mohammad, 1996, Alam Pikiran Yunani, (Jakarta: Tinta Mas.

Heriyanto, Husain, 2003, Paradigma Holistik: Dialog Filsafat, Sains, dan Kehidupan Menurut Shadra dan Whitehead, Jakarta: Teraju. 
Ibnu Katsir, Al-Imam Abul Fida Isma'il ad-Dimasyqi, 2000, Tafsir Ibnu Katsir, Peterj.: Bahrun Abu Bakar, Juz. 2, Bandung: Sinar Baru Algensindo.

Kathy S. Stolley, 2005, The Basics of Sociology, London: Greenwood Press.

Kuhn, Thomas, 1970, The Structure of Scientific Revolutions, Chicago: The University of Chicago Press.

Kuntowijoyo, 1991, Paradigma Islam: Intepretasi untuk Aksi, Bandung: Mizan,

Langgulung, Hasan, 1998, Pendidikan Islam Menghadapi Abad Ke-21, Jakarta: Pustaka Al-Husna.

Madjid, Nurcholish, 2000, Dialog Ramadhan Bersama Cak Nur: Merenungi Makna dan Hikmah Ibadah Puasa, Nuzulul Qur'an, Lailatur Qadr, Zakat, dan Idul Fitri, Jakarta: Paramadina.

, 2000, Dialog Ramadhan Bersama Cak Nur: Merenungi Makna dan Hikmah Ibadah Puasa, Nuzulul Qur'an, Lailatur Qadr, Zakat, dan Idul Fitri, Jakarta: Paramadina.

Masdar Hilmy, 2008, Islam Profetik: Substansiasi Nilai-Nilai Agama dalam Ruang Publik, Yogyakarta: Kanisius.

Nicholson, Reynold A., 1991, Studies in Islamic Mysticisme, London: Cambridge, University Press.

P.A. Van der Weij, 1991, Filsuf-Filsuf Besar Tentang Manusia, Peterj.: K. Bertens, Jakarta: Gramedia Pustaka Utama.

Pujiono, Abd. Hamid, 2003, Manusia Menyatu dengan Tuhan, Surabaya: Target Press,

Rachman, Budhy Munawar, (Edit.), 1995, Kontekstualisasi Doktrin Islam dalam Sejarah, Jakarta: Paramadina,.

Raharjo, M. Dawam (Edit.), 1987, Insan Kamil Konsepsi Menurut Islam, Jakarta: Graffiti Press.

Rahman, Fazlur, 1980, Islamic Studies and The Future of Islam, (California: Malibu,). 
, 1980, Major Themes Of The Qur'an. (Chicago:

Minneapolis Bibliotheca Islamica.

, 1984, Islam, Peterj: Ahsin Muhammad, (Bandung: Pustaka.

, Islam and Modernity. Chicago: The University of Chicago, 1980).

Ritzer, George (Edit.), 2005, Encyclopedia of Social Theory, Jilid II, London: SAGE Publications.

Rukmana, Aan dkk., 2012, Mengenal Islam Jalan Tengah: Buku Daras Pendidikan Agama Islam untuk Perguruan Tinggi, Jakarta: Dian Rakyat.

Schuon, Frithof, 1981, Understanding Islam, Peterj.: D.M. Matheson, London: Unwin Paperbacks.

Sumanta, 2007, al-Insan al-Kamil dalam Perspektif Tasawuf: Studi Komparasi antara Tasawuf al-Ghazali dan al-Jilli, (Disertasi), Jakarta: Sekolah Pascasarjana Universitas Islam Negeri Syarif Hidayatullah.

Tafsir, Ahmad, 2001, Filsafat Umum: Akal dan Hati Sejak Thales Sampai Capra, (Bandung: Remaja Rosdakarya,.

Tobroni, 2015, Pendidikan Islam: dari Dimensi Paradima Teologis, Filosofis, dan Spiritualitas hingga Dimensi Praksis Normatif, Jakarta: Mitra Wacana Media. 